Session 2560

\title{
Development of Social Literacy in First Year Engineering Curriculum
}

\author{
Josef Rojter \\ Department of Mechanical Engineering \\ Victoria University of Technology \\ P.O. Box 14428, MMC \\ Melbourne \\ VIC 8000 \\ Australia
}




\begin{abstract}
A revised first year curriculum in a subject, Engineering in Society, was introduced in the Department of Mechanical Engineering at Victoria University of Technology (VUT). The revision was thought to be necessary because of structural weakness in the curriculum and poor perception of the subject by academic staff and students. The outcome of the new curriculum was measured through a questionnaire at the end of the semester. The response of the students to this survey placed the subject in the the difficult and complex arena in the academic domain, but the results of the survey also suggested high satisfaction with the new curriculum and indicated that it provided an interesting path into the discipline and profession of engineering.
\end{abstract}

\title{
INTRODUCTION
}

In 1996 the faculty of engineering introduced a new first year subject, Engineering in Society. This was done ( though belatedly) in accordance with 1987 Williams Committee and the Institution of Engineers, Australia, recommendations. Both of the bodies argued for greater proportion of engineering curricula be set aside for subjects dealing with non-technical matters, concerning social and managerial literacies. The Review Committee on Engineering Education chaired by Professor Peter Johnson (1995) argued for distinguishing engineering from applied science through the emphasis on the multivariant knowledge base needed in engineering practice.

VUT, a relatively new university is located in an industrial area of Melbourne, an area possessing a lower socio-economic profile. Among the state's universities, VUT is positioned lowly as far as institutional prestige and attractiveness to high quality entrants is concerned. The faculty of engineering more than reflects the university's lack of desirability despite the well recognised high quality of teaching within the faculty. The student intake base has the highest proportion of students coming from non-english speaking background in Australia and that was reflected by poor communication skills, poor knowledge base, lack of social awareness and understanding of engineering. Changes in engineering curricula were needed to expand the base of more academically able of students and to enhance the basic skills among the existing students so as to improve the attrition rates.

The introduction of the new first year one semester subject was guided by four philosophical imperatives:

- To enhance social and cultural literacies within the existing engineering curricula.

- To enhance oral and communication skills.

- "Soften" the image of engineering and enhance the attractiveness of engineering courses to prospective students. Surveys undertaken among secondary students showed low attractiveness of engineering compared to other fields of study.Engineering was considered to be too positivist and not people-oriented discipline.

- Improve the attrition rate among first year engineering students. 
The subject, Engineering and Society, was introduced in 1996 as a common course in mechanical, civil and building engineering streams. The syllabus of the course as its centrepiece placed an emphasis on engineering practice and its relation to society. Controversial issues such as ecology, environment and the impact of technology on society were used as prisms through which engineering practice could be explored. Subsequent surveys undertaken among first year students suggested that the subject did not capture students imagination, many students rating the subject as uninteresting and of little relevance. The same survey also showed the subject to lack academic rigour and its redeeming feature being easy to pass.

\section{PROCESS}

The perceived lack of academic rigour and the perception of poor academic standing of this subject led the Department of Mechanical Engineering to revise the curriculum and structure of this subject. The new syllabus was unpacked into two components:

1. Component addressing comprehension and communication needs. The one semester subject had one hour tutorial per week set aside to the development of the abovementioned skills. Here, the students were required to keep a diary and undertook exercises in summarising the lecture notes. The students also were required to develop an argument on a set topic which required, at the end of semester, written and oral presentation. The oral presentation took the form of a team debate. The responsibility of running and assessing this component was allocated to the Department of Humanities.

2. Component that addressed the social structures and their parts. Engineers were positioned as agents of social change and their role was located in the domain of social production. One hour lecture and one hour tutorial per week was dedicated to this component. The students were required to part-take in tutorial discussions and present short tutorial papers. The research part of this component required the students to submit two well argued essays on controversial topics, the arguments being substantiated by bibliography. The responsibility for delivering this component was the province of Department of Mechanical Engineering. Typical course structure for this component is shown at the back of this paper.

Both of the two components converged at the end of the semester through the process of a debate exercise. Debating teams of three were formed out of the student body, each set of two teams were provided with a topic where opposing views had to be articulated through the process of thorough research under the guidance of humanities tutor and a librarian. Details of the research were documented by each student in their personal diary and be open to scrutiny. The ensuing debate and research notes constituted part of the subject assessment. The objective here was to instil teamwork culture and to play a part in the development of verbal communication skills.

\section{SYLLABUS}

The new syllabus of the subject was based on Professor Hardy Cross's model of engineering profession (fig. 1). 


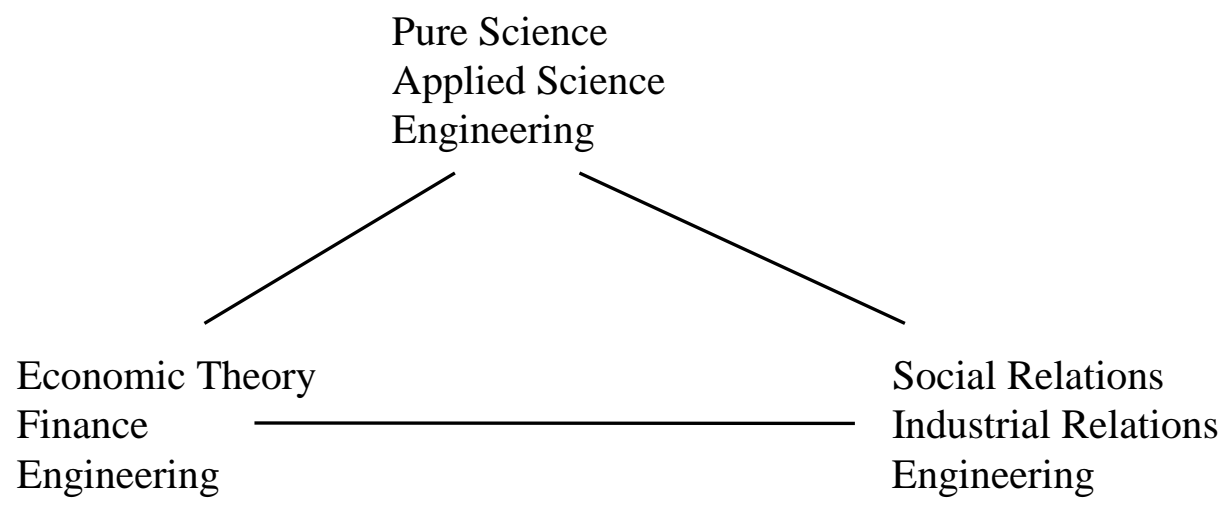

Fig. 1

The new syllabus took the form of brief topics with the intention of opening up a number of windows that reflected the knowledge base used in engineering practice. The topics were also designed to front engineering as an activity representing a human endeavour. The topics were:

- Engineering practice. What do engineers do? Distinction between science,technology and engineering practice.

- Brief introduction to the history of technology and engineering. The role engineers played in the evolution of society and civilisations.

- Knowledge required in engineering practice. Relationship between kinds of knowledge; holistic, male, female, to engineering practice and its perspective, be it positivist, utilitarian or ethical.

- Influence and role of ethics in engineering practice. Importance of value systems in the development of ethical framework.

- Application of engineering principles in the analysis of semi-technical problems. Illustration of second law of thermodynamics as a tool for environmental impact studies.

- Engineer as a manager of change. Issues of change and societal responses to change.

- Ecological issues in engineering. Case studies.

- Principles of environmental sustainable development (ESD).

- Economic perspectives. Simple economic terms are defined and major economic theories are introduced. The outcome of government's economic policies is examined in terms of the theoretical models. 


\section{DISCUSSION}

How good is the new syllabus? The evaluation based on student survey addressed both the teaching style and it's effectiveness and the subject curriculum. It is the latter that is in question here and worthy of study. There were 67 students who responded to the questionnaire and this represented 62 percent of total subject enrolment. The responses to relevant questions are shown in table 1 below:

Table 1. Questions concerning the subject curriculum

\begin{tabular}{|c|c|c|c|}
\hline Question & Responses & $\begin{array}{l}\text { Number } \\
\text { responding }\end{array}$ & $\begin{array}{l}\text { Percent } \\
\text { response }\end{array}$ \\
\hline $\begin{array}{l}\text { Do you feel that the } \\
\text { subject content is } \\
\text { relevant to the discipline } \\
\text { of engineering? }\end{array}$ & $\begin{array}{l}\text { Very relevant } \\
\text { Relevant } \\
\text { Of some relevance } \\
\text { Not relevant } \\
\text { Waste of time }\end{array}$ & $\begin{array}{l}18 \\
28 \\
14 \\
5 \\
2\end{array}$ & $\begin{array}{c}26.9 \\
41.8 \\
20.9 \\
7.4 \\
3.0\end{array}$ \\
\hline $\begin{array}{l}\text { Did you find the subject } \\
\text { matter...? }\end{array}$ & $\begin{array}{l}\text { Very Interesting } \\
\text { Interesting } \\
\text { Neither Interesting nor } \\
\text { uninteresting } \\
\text { Uninteresting } \\
\text { Boring }\end{array}$ & $\begin{array}{c}19 \\
30 \\
9 \\
\\
5 \\
4\end{array}$ & $\begin{array}{l}28.4 \\
44.8 \\
13.4 \\
7.4 \\
6.0\end{array}$ \\
\hline $\begin{array}{l}\text { To what extent did the } \\
\text { subject influence you? }\end{array}$ & $\begin{array}{l}\text { To continue with your current } \\
\text { course. } \\
\text { Played no influential role on your } \\
\text { decision to whether continue or } \\
\text { discontinue your current course. } \\
\text { To discontinue with all studies } \\
\text { To change to another engineering } \\
\text { course. } \\
\text { To change your studies to } \\
\text { humanities/social studies/ } \\
\text { management based courses. }\end{array}$ & $\begin{array}{l}48 \\
0 \\
0\end{array}$ & $\begin{array}{l}71.6 \\
0 \\
0\end{array}$ \\
\hline $\begin{array}{l}\text { In terms of academic } \\
\text { complexity, did you find } \\
\text { this subject to be? }\end{array}$ & $\begin{array}{l}\text { Among the three most difficult } \\
\text { subjects. } \\
\text { Of average difficulty. } \\
\text { Among the three easiest subjects. }\end{array}$ & $\begin{array}{c}41 \\
22 \\
4\end{array}$ & $\begin{array}{r}61.2 \\
32.8 \\
6.0\end{array}$ \\
\hline $\begin{array}{l}\text { In terms of assignment } \\
\text { and study time, did you } \\
\text { find this subject.. }\end{array}$ & $\begin{array}{l}\text { Among the three subjects requiring } \\
\text { the most time? } \\
\text { Requiring about average amount } \\
\text { of time? } \\
\text { Among the three subjects requiring }\end{array}$ & $\begin{array}{l}40 \\
22 \\
5\end{array}$ & $\begin{array}{l}59.7 \\
32.8 \\
7.5\end{array}$ \\
\hline
\end{tabular}




\begin{tabular}{|l|l|c|c|}
\hline & least amount of time? & & \\
\hline In advising new & Highly recommend this subject. & 24 & 35.8 \\
oncoming students, & Recommend this subject? & 34 & 50.7 \\
would you... & Express a neutral opinion on this & 7 & 10.5 \\
& subject? & 1 & 1.5 \\
& Not recommend this subject? & 1 & 1.5 \\
\hline
\end{tabular}

The student survey reflected a positive attitude towards the new subject. The students thought that overall the subject was fairly complex requiring above average work input, though on the other hand, this subject was found interesting and a recommended academic activity. Interestingly, the survey also indicated that the subject had a positive influence on students to continue with engineering study and further influence to continue with all tertiary studies.

\section{CONCLUDING REMARKS}

The initial introduction of the subject dealing with social and economic literacy had more to do with the notion of softening the image of engineering than providing a respectable addition to the engineering curriculum. The fine tuning of this subject changed the original intent by ironing out the initial problems and general dissatisfaction with the academic quality of the subject. The new subject syllabus may pave for an eight semester course dealing with social and managerial literacy within the undergraduate engineering curriculum. It is also hoped that the new subject may act as foundations of a course dealing with technological and engineering literacy that could be offered to undergraduate programs in humanities, social sciences and management.

\section{$\underline{\text { Biographical Details }}$}

The author after qualifying in science and chemical engineering engineering spent some time in the plastics industry.Since his academic appointment,initially at the Royal Melbourne Institute ofTechnology he completed masters degrees in science and materials engineering while teaching and researching in materials and chemical engineering. He is currently completing a doctoral thesis on epistemological influences in professional engineering education. 